\title{
Understanding the population genetics of Plasmodium vivax is essential for malaria control and elimination
}

\author{
Alicia Arnott ${ }^{1}$, Alyssa E Barry ${ }^{2,3}$ and John C Reeder ${ }^{1,4^{*}}$
}

\begin{abstract}
Traditionally, infection with Plasmodium vivax was thought to be benign and self-limiting, however, recent evidence has demonstrated that infection with $P$. vivax can also result in severe illness and death. Research into $P$. vivax has been relatively neglected and much remains unknown regarding the biology, pathogenesis and epidemiology of this parasite. One of the fundamental factors governing transmission and immunity is parasite diversity. An understanding of parasite population genetic structure is necessary to understand the epidemiology, diversity, distribution and dynamics of natural P. vivax populations. In addition, studying the population structure of genes under immune selection also enables investigation of the dynamic interplay between transmission and immunity, which is crucial for vaccine development. A lack of knowledge regarding the transmission and spread of $P$. vivax has been particularly highlighted in areas where malaria control and elimination programmes have made progress in reducing the burden of Plasmodium falciparum, yet $P$. vivax remains as a substantial obstacle. With malaria elimination back on the global agenda, mapping of global and local $P$. vivax population structure is essential prior to establishing goals for elimination and the roll-out of interventions. A detailed knowledge of the spatial distribution, transmission and clinical burden of $P$. vivax is required to act as a benchmark against which control targets can be set and measured. This paper presents an overview of what is known and what is yet to be fully understood regarding $P$. vivax population genetics, as well as the importance and application of $P$. vivax population genetics studies.
\end{abstract}

Keywords: Plasmodium vivax, Malaria, Population genetics, Microsatellites, Genetic diversity, Elimination

\section{Plasmodium vivax: a global health threat}

Presently, 2.85 billion people globally are at risk of Plasmodium vivax malaria infection [1]. Worldwide the regional incidence of $P$. vivax has been increasing despite a decrease in Plasmodium falciparum cases [2-5]. The most geographically widespread of the six Plasmodium species that infect humans, $P$. vivax is a major health threat to huge populations throughout Asia, the Middle East and the Pacific [1], where approximately 80 to $90 \%$ of the global P. vivax burden is concentrated [6]. A significant number of $P$. vivax cases also occur throughout Central and South America, and East and South Africa [6]. Despite this, research into P. vivax malaria has been relatively neglected and much detail of the biology,

\footnotetext{
* Correspondence: jreeder@burnet.edu.au

${ }^{1}$ Centre for Population Health, Burnet Institute, Melbourne, Australia Full list of author information is available at the end of the article
}

pathogenesis and epidemiology of this parasite remains unknown. Traditionally, infection with $P$. vivax was thought to be benign and self-limiting and was not considered a research priority in comparison with the enormous burden of morbidity and mortality presented by $P$. falciparum $[7,8]$. Recent evidence is however challenging the long-held notion of the benign nature of $P$. vivax malaria, demonstrating that infection with $P$. vivax can also result in severe illness and death [9-14]. Indeed, the severe manifestations of $P$. vivax disease are very similar to those caused by P. falciparum and include cerebral malaria, acute respiratory distress, lung injury, renal failure, hepatic dysfunction, shock and death [12,14].

Lack of knowledge regarding the transmission and spread of $P$. vivax has been particularly highlighted in areas where malaria control and elimination programmes have made progress in reducing the burden of

\section{C) Biomed Central}


$P$. falciparum, yet $P$. vivax remains as a substantial obstacle [15]. The emergence and spread of drug resistant $P$. vivax is also of serious concern. Indeed, in the context of achieving malaria elimination targets, reports of primaquine resistance, the only available treatment to prevent relapse, is particularly worrisome [16,17]. One of the key problems undermining effective malaria control is a lack of understanding of the underlying $P$. vivax population structure and transmission dynamics. Population genetic studies are needed to define the diversity, distribution and dynamics of $P$. vivax populations, as parasite populations differ widely between locations, due to factors including prevalence, vector species, host genetics and a variety of environmental influences [18-21]. Mapping of global and local $P$. vivax population structure is essential prior to establishing goals for elimination and the rollout of interventions, and detailed knowledge of the spatial distribution, transmission and clinical burden of $P$. vivax is required to act as a benchmark against which control targets can be set and measured $[1,19,22,23]$. The Malaria Eradication Research Agenda (malERA) Consultative Group on Basic Science and Enabling Technologies recently reported that no campaign for malaria control or elimination can proceed without a comprehensive knowledge of disease epidemiology and host-parasite-vector interactions, and how these interactions are affected by intensified intervention measures [24].

\section{Genetic diversity of Plasmodium vivax}

Within a malaria endemic area, multiple parasite clones can often co-infect the same host. To understand local population structure and genetic diversity, it is essential to be able to distinguish between distinct clones within the same infection as well as between infections. Not only useful in the context of molecular epidemiology studies, identifying and managing multiple clone infections may have additional public health implications, as increasing, or high levels of multiple clone P. vivax infections may drive increases in parasite virulence and fitness, as parasite clones compete for both resources within the infected host and survival against antimalarial interventions [25]. However, identifying, and distinguishing between clones can be difficult because the genetic diversity of $P$. vivax populations can vary significantly due to variations in malaria epidemiology in different regions [26,27]. Isolates obtained from distinct populations can either be genetically very diverse, so that multiple infections are easy to determine using a single molecular marker, or they can have quite low levels of diversity or even be clonal in the case of very low transmission or epidemics, which makes it more difficult to distinguish polyclonal from true monoclonal infections [28].
Genotyping to determine the multiplicity of infection (MOI) can be performed using either one or two markers that are extremely polymorphic, or a larger number of less polymorphic genome-wide markers. Currently, regions of the genome containing polymorphic repeat sequences, such as microsatellites or surface antigen genes, are the markers of choice for doing this. Microsatellite markers are short, tandem, one to six nucleotide repeats, found frequently throughout the genome and are typically, selectively neutral. Prior to the identification of microsatellites, earlier studies genotyped strains on the basis of polymorphic coding regions within parasite antigens such as the circumsporozoite protein (CSP) and the merozoite surface protein 3 alpha (MSP-3 $\alpha$ ), for which there are fewer alleles than the microsatellite markers [25,29]. Therefore, the number of clones per infection was most likely underestimated (Table 1).

The population genetic structure of $P$. falciparum is closely associated with transmission intensity, hence population structure and diversity varies greatly according to geographical location, at least on a global scale $[65,66]$. Plasmodium falciparum populations in regions with low levels of transmission generally have low proportions of polyclonal infection high levels of linkage disequilibrium (LD) suggesting significant inbreeding and infrequent recombination. The inverse is also true, with parasite populations in high transmission areas characterized by a high proportion of multiple infections low levels of LD suggesting significant outcrossing and frequent recombination $[27,65]$. Few studies have been performed amongst sympatric populations of $P$. vivax and P. falciparum, however from what is known, there appears to be a distinctly different model of population structure for $P$. vivax compared to that of $P$. falciparum $[2,25,27,37]$. Using samples collected from a low transmission setting in rural Amazonia, Ferreira and colleagues reported higher genetic diversity and frequency of polyclonal infections for $P$. vivax compared to $P$. falciparum [2]. Interestingly, strong LD, and frequent replacement of predominant microsatellite haplotypes over time was also observed amongst the same $P$. vivax population [2]. The unique biology of $P$. vivax is likely to be responsible for the apparent paradox of multiple clone infection in a low transmission setting. The latent hypnozoite stage of the $P$. vivax lifecycle increases the likelihood of superinfection with a second clone, potentially resulting in the reactivation of heterologous hypnozoites and an increased likelihood of meiotic recombination, ultimately increasing genetic diversity within the population [2,33].

Indeed, microsatellite genotyping has revealed that the level of genetic variability is highly variable among distinct $P$. vivax populations worldwide. Using the same panel of 17 microsatellites, $100 \%$ of $P$. vivax infections in southern 
Table 1 Global detection of multiple clone infections using molecular markers in Plasmodium vivax populations

\begin{tabular}{|c|c|c|c|c|c|c|}
\hline $\begin{array}{l}\text { Study } \\
\text { region }\end{array}$ & Study [reference] & $\begin{array}{l}\text { Year samples } \\
\text { collected }\end{array}$ & $\begin{array}{l}\text { Number of samples } \\
\text { analysed }\end{array}$ & Marker & $\begin{array}{l}\text { Proportion infections with } \\
\text { multiple clones (\%) }\end{array}$ & $\begin{array}{l}\text { Mean } \\
\text { MOI }\end{array}$ \\
\hline \multicolumn{7}{|l|}{ Asia } \\
\hline \multirow[t]{4}{*}{ Thailand } & $\begin{array}{l}\text { Imwong et al. } 2007 \\
{[27]}\end{array}$ & 1992-1993 & 92 & Microsatellites & $30->60$ & 1.4 \\
\hline & $\begin{array}{l}\text { Imwong et al. } 2005 \\
{[30]}\end{array}$ & 1995-1998 & 100 & $\mathrm{CSP}+\mathrm{MSP} 1$ & 26 & 1.29 \\
\hline & & & & $\mathrm{MSP} 3 \alpha$ & 19.3 & \\
\hline & & & & $\mathrm{CSP}+\mathrm{MSP} 3 \alpha$ & 35.6 & \\
\hline Laos & $\begin{array}{l}\text { Imwong et al } 2007 \\
{[27]}\end{array}$ & $2001-2003$ & 81 & Microsatellites & $30->60$ & 1.5 \\
\hline Vietnam & $\begin{array}{l}\text { Van den Eede et al. } \\
2010 \text { [33] }\end{array}$ & $1999-2000$ & 69 & Microsatellites & 100 & 3.7 \\
\hline \multirow[t]{3}{*}{ India } & $\begin{array}{l}\text { Prajapati et al. } 2006 \\
\text { [34] }\end{array}$ & $2000-2004$ & 252 & GAM-1 & 13.09 & $N / S$ \\
\hline & $\begin{array}{l}\text { Imwong et al. } 2007 \\
\text { [27] }\end{array}$ & 2003-2004 & 90 & Microsatellites & $10-40$ & 1.2 \\
\hline & Kim et al. 2006 [35] & 2003-2004 & 151 & CSP, MSP1, MSP3 $\alpha$ & 10.6 & $N / S$ \\
\hline \multirow[t]{4}{*}{ Sri Lanka } & $\begin{array}{l}\text { Wickramara-chchi et al. } \\
2010 \text { [36] }\end{array}$ & $1998-2000$ & 201 & MSP3 $\alpha$ & $13.8-20$ & $N / S$ \\
\hline & $\begin{array}{l}\text { Karunaweera et al. } \\
2008[26]\end{array}$ & 2005 & 50 & Microsatellites & $9.1-60$ & $N / S$ \\
\hline & $\begin{array}{l}\text { Gunawardena et al. } \\
2010[37]\end{array}$ & 2003-2008 & 140 & Microsatellites & 55 & $N / S$ \\
\hline & & & & $\mathrm{MSP} 3 \alpha$ & 6 & $N / S$ \\
\hline \multirow[t]{3}{*}{ Pakistan } & $\begin{array}{l}\text { Khatoon et al. } 2010 \\
\text { [38] }\end{array}$ & {$[2007]$} & 50 & MSP3 $\beta$ & 12 & \\
\hline & & & & $M S P 3 \alpha+M S P 3 \beta$ & 2 & $N / S$ \\
\hline & Zakeri et al. 2010 [39] & 2008 & 187 & CSP, MSP-1, MSP3 $\alpha$ & 30 & \\
\hline \multirow[t]{5}{*}{ China } & & 2004 & 54: Anhui Province & & 5.6 & $N / S$ \\
\hline & Yang et al. 2006 & 2005 & 31: Guizhou Province & MSP3 $\beta$ & 0 & \\
\hline & & 2004 & 14: Guangxi Province & & 0 & \\
\hline & Zhong et al. 2011 [41] & $2006-2008$ & 140 & $\mathrm{MSP} 3 \alpha$ & 7.6-14.3 & $N / S$ \\
\hline & & & & MSP3 $\beta$ & $14.3-15$ & \\
\hline \multirow[t]{7}{*}{ Myanmar } & Kim et al. 2010 [42] & 2000 & 96 & CSP & 24.5 & $N / S$ \\
\hline & & & & CSP & 24.1 & $N / S$ \\
\hline & Moon et al. 2009 [43] & 2004 & 349 & & MSP1 & 16.4 \\
\hline & & & & MSP3 $\alpha$ & 21.6 & \\
\hline & Zhong et a.l 2011 [41] & $2006-2008$ & 72 & $\mathrm{MSP} 3 \alpha$ & 10.2 & $N / S$ \\
\hline & & & & MSP3 $\beta$ & 16.4 & \\
\hline & $\begin{array}{l}\text { Gunawardena et al. } \\
2010 \text { [37] }\end{array}$ & 2007 & 167 & Microsatellites & 67.1 & $N / S$ \\
\hline East Timor & Chen et al. 2007 [44] & 2001 & 17 & CSP, MSP-1, AMA-1 & 35 & $\mathrm{~N} / \mathrm{S}$ \\
\hline \multicolumn{7}{|l|}{ Middle East } \\
\hline \multirow[t]{4}{*}{ Iran } & Zakeri et al. 2003 [45] & $2000-2001$ & 107 & MSP-1 & 20 & $\mathrm{~N} / \mathrm{S}$ \\
\hline & Zakeri et al. 2006 [46] & $2000-2003$ & 374 & CSP & 12 & $\mathrm{~N} / \mathrm{S}$ \\
\hline & Zakeri et al. 2006 [47] & $2000-2003$ & 144 & MSP3 $\alpha$ & 3.5 & $N / S$ \\
\hline & Zakeri et al. 2010 [39] & 2008 & 150 & CSP, MSP-1, MSP3 $\alpha$ & 24.6 & $\mathrm{~N} / \mathrm{S}$ \\
\hline \multirow[t]{2}{*}{ Uzbekistan } & $\begin{array}{l}\text { Severini et al. } 2004 \\
\text { [48] }\end{array}$ & $1999-2002$ & 12 indigenous cases & MSP-1 & 8 & $\mathrm{~N} / \mathrm{S}$ \\
\hline & & & 10 imported cases & & 10 & \\
\hline \multirow[t]{3}{*}{ Afghanistan } & & & & CSP & 6.4 & \\
\hline & Zakeri et al. 2010 [49] & 2007 & 202 & MSP-1 & 0 & $\mathrm{~N} / \mathrm{S}$ \\
\hline & & & & $\mathrm{MSP} 3 \alpha$ & 3.5 & \\
\hline
\end{tabular}


Table 1 Global detection of multiple clone infections using molecular markers in Plasmodium vivax populations (Continued)

\begin{tabular}{|c|c|c|c|c|c|c|}
\hline Turkey & Zeyrek et al. 2010 [50] & $2007-2008$ & 31 & MSP-1 & 3.2 & $N / S$ \\
\hline Africa & & & & & & $\mathrm{N} / \mathrm{S}$ \\
\hline Ethiopia & $\begin{array}{l}\text { Gunawardena et al. } \\
2010 \text { [37] }\end{array}$ & $2006-2008$ & 118 & Microsatellites & 73.70 & $\mathrm{~N} / \mathrm{S}$ \\
\hline \multicolumn{7}{|c|}{ South \& Central America } \\
\hline Mexico & Joy et al. 2008 [20] & $1997-2005$ & 234 & Microsatellites & 15.8 & 1.01 \\
\hline \multirow[t]{2}{*}{$\overline{\text { Peru }}$} & Sutton et al. 2009 [51] & $2003-2004$ & 186 & MSP3 $\alpha$ & 26.3 & $2-3^{a}$ \\
\hline & $\begin{array}{l}\text { Van den Eede et al. } \\
2010 \text { [28] }\end{array}$ & $2006-2008$ & 159 & Microsatellites & $11-70$ & 1.1 \\
\hline \multirow[t]{6}{*}{ Brazil } & Ferreira et al. 2007 [2] & 1999 & 74 & Microsatellites & 48 (1999) & $N / S$ \\
\hline & & $2004-2005$ & & & $49(2004-5)$ & \\
\hline & $\begin{array}{l}\text { Rezende et al. } 2009 \\
{[52]}\end{array}$ & 2003-2005 & 44 & Tandem repeats & $0-66$ & $N / S$ \\
\hline & $\begin{array}{l}\text { Rezende et al. } 2010 \\
\text { [53] }\end{array}$ & $2003-2005$ & 53 & Microsatellites & $32-57$ & $N / S$ \\
\hline & $\begin{array}{l}\text { Storti- Melo et al. } 2009 \\
\text { [54] }\end{array}$ & 2003-2005 & 155 & CSP & $0-39.3$ & $N / S$ \\
\hline & $\begin{array}{l}\text { Orjuela-Sanchez et al. } \\
2009 \text { [55] }\end{array}$ & $2005-2007$ & 77 & Microsatellites & $10.1-42.4$ & $N / S$ \\
\hline \multirow{3}{*}{$\begin{array}{l}\text { French } \\
\text { Guiana }\end{array}$} & & & & MSP-1 (57 samples) & 12.3 & $N / S$ \\
\hline & Veron et al. 2009 [56] & $2005-2006$ & 109 & $\begin{array}{l}\text { MSP3 } \alpha \text { (109 } \\
\text { samples) }\end{array}$ & 13.8 & \\
\hline & & & & $\begin{array}{l}\text { MSP-1 + MSP3 } \alpha \text { (57 } \\
\text { samples) }\end{array}$ & 21 & \\
\hline Guyana & Bonilla et al. 2006 [57] & 2000 & 61 & CSP & 39.3 & $N / S$ \\
\hline \multirow[t]{2}{*}{ Colombia } & $\begin{array}{l}\text { Imwong et al. } 2007 \\
{[27]}\end{array}$ & $2001-2003$ & 82 & Microsatellites & $10-40$ & 1.1 \\
\hline & $\begin{array}{l}\text { Cristiano et al. } 2008 \\
\text { [58] }\end{array}$ & 2006 & 55 & $\mathrm{MSP} 3 \alpha$ & 36.4 & $N / S$ \\
\hline \multirow[t]{2}{*}{ Venezuela } & Ord et al. 2005 [59] & 1995-1997 & 58 & $\mathrm{MSP} 3 \alpha$ & 10 & $N / S$ \\
\hline & Leclerc et al. 2005 [60] & Not stated & 39 & MSP-1 & 0 & N/A \\
\hline \multicolumn{7}{|l|}{ Oceania } \\
\hline \multirow[t]{5}{*}{$\begin{array}{l}\text { Papua New } \\
\text { Guinea }\end{array}$} & $\begin{array}{l}\text { Henry-Halldin et al. } \\
2011 \text { [61] }\end{array}$ & $2001-2003$ & 703: Wosera region & CSP & 36.8 & $N / S$ \\
\hline & & & 986: Mugil region & & 34.4 & \\
\hline & Mueller et al. 2002 [62] & 2002 & 11 & $\mathrm{MSP} 3 \alpha$ & 18 & $N / S$ \\
\hline & Koepfli et al. 2009 [63] & $2004-2005$ & 108 & Microsatellites & 81.4 & $1-8$ \\
\hline & Gomez et al. 2003 [64] & Not stated & 89 & pvMS1 & 4.5 & $\mathrm{~N} / \mathrm{S}$ \\
\hline
\end{tabular}

${ }^{a}$ Mean $\mathrm{MOI}$ was not reported, shown is the observed $\mathrm{COI}$ range

N/S: Mean MOI was not reported; N/A: none of the samples tested were polyclonal

Vietnam were found to be polyclonal [33], compared to $11-70 \%$ polyclonality observed following analysis of isolates collected in the Peruvian Amazon [28] (Table 1). Similarly, when using a panel of nine microsatellites Imwong and colleagues reported low genetic diversity, high levels of inbreeding and linkage disequilibrium in Colombia, compared to high levels of genetic diversity in India, Thailand and Laos [27] (Table 1). These results emphasize that it cannot be assumed that global parasite populations are equivalent and as a result, may not be impacted by intervention measures to the same extent.
In order to enable accurate comparisons of genetic diversity of global $P$. vivax populations, a standardized approach to microsatellite genotyping is required, similar to that implemented for investigation of $P$. falciparum [67]. However, there remain a number of challenges and limitations to developing such an approach. Selection of both the appropriate number and length of microsatellites to be used for genotyping is crucial to obtain accurate results [29]. Increasing the number of markers investigated increases the likelihood of detecting multiple clone infections. Havryliuk and colleagues reported that a 
combination of nine markers was sufficient to identify $90 \%$ of multiple clone infections amongst samples collected in Acre, Brazil and that 11 markers enabled 100\% of multiple clone infections to be identified [25]. In addition, it is known that repeat length can influence diversity associated with a microsatellite, with longer arrays of di-, tri- and tetra-nucleotide repeats more diverse than shorter sequences $[2,53,68-71]$.

The diversity of a given microsatellite, and the number of microsatellites required to accurately genotype $P$. vivax strains will differ in different epidemiological settings and geographic regions [27,33,63]. Gunawardena and colleagues reported diversity of the MS16 microsatellite was far higher amongst Sri Lankan P. vivax strains compared to strains collected in Ethiopia, despite a higher rate of polyclonal infections detected amongst the Ethiopian samples tested [37] (Table 1). A similarly high level of MS16 diversity was observed by Koepfli and colleagues, reporting that more clones were detected using MS16, compared with the MSP1-f3 marker amongst strains from Papua New Guinea (PNG), due to a greater likelihood of clones sharing the same MSP1-f3 allele [72]. Furthermore, the same authors also demonstrated that in the context of a multiple clone infection, clones representing a minority of the population may be missed by PCR, and that detectability of specific $P$. vivax clones in a particular individual varied depending on the day that sample was collected [72]. Taken together, these results suggest that prior to development of a standardized strategy for $P$. vivax genotyping, the suitability of candidate markers must be widely assessed in distinct populations. In addition to identifying suitable markers, the criteria for assigning minor/ multiple alleles must also be standardized to further limit discrepancies reported between studies.

\section{The importance of Plasmodium vivax population genetics studies \\ Identifying routes of transmission and gene flow}

Investigating the genetic diversity of Plasmodium vivax populations is essential from both a public health perspective, and

to help achieve malaria control and elimination. Detection and analysis of individual clones within populations has not only provided a greater understanding of genetic diversity, but also of $P$. vivax prevalence and incidence $[31,46,73,74]$. Prevalence is one indicator of transmission and the main malariometric measurement in investigations including the global Malaria Atlas Project (MAP) [75]. For control and elimination strategies to succeed, the origin and movement of $P$. vivax populations must be identified, which can be achieved by genotyping isolates from several different regions. Using a panel of 12 microsatellite markers, Gunawardena and colleagues reported that isolates collected in Sri Lanka, Myanmar and Ethiopia all clustered according to their geographic origins, demonstrating that these microsatellites may be used to map the origin of $P$. vivax isolates, at least on a broad continental scale [37]. Genome-wide single nucleotide polymorphisms (SNPs) may provide a higher resolution for geographic positioning on a local scale, however such SNPs have not yet been identified for P. vivax.

The construction of population structure networks and maps demonstrating genetic relatedness of parasites in specific regions can enable not only the identification of parasite origins but also routes of population movement, and therefore the likelihood of successful elimination within a given region with respect to parasite diversity, population movement and the burden of imported cases [76]. The Pacific Malaria Initiative (PacMI) recently reported the results of an epidemiological survey performed in order to investigate the likelihood of success of potential malaria elimination campaigns in two isolated island provinces of Vanuatu and the Solomon Islands, Tafea and Temotu provinces, respectively [77]. The results of prior studies conducted in other provinces of both nations reported a predominance of $P$. falciparum, with high parasite prevalence (up to 35\%) and transmission rates [77-80]. Although extensive genetic characterization of the parasite populations was not performed, the results of the recent PacMI survey revealed that compared to other provinces within each country, the malaria epidemiology in the isolated Tafea and Temotu provinces was hypoendemic, with low parasite prevalence and a predominance of $P$. vivax [77]. Coupled with restricted travel and screening of incoming passengers for infection with malaria parasites, both island provinces were flagged as candidates for future malaria elimination campaigns [77].

Porous land borders between malaria endemic countries, specifically throughout Southeast Asia and the Middle East, are potential barriers to the successful implementation of malaria elimination campaigns $[77,81]$. Migration of infected individuals resulting in importation of Plasmodium spp. and subsequent transmission by local vectors has contributed to the global spread of malaria [82]. Migration of infected individuals may seriously confound containment of $P$. vivax, as individuals can be unaware of their infection status due to long incubation periods. Hence, the potential for reintroduction of endemic malaria into non-endemic countries, is high. Khan and colleagues recently reported both detection of competent malaria vectors and an increase in malaria cases, mostly due to $P$. vivax, in Qatar, due to a massive influx of migrant workers from India and Pakistan [83]. Imported cases also have the potential to increase genetic diversity of existing $P$. 
vivax populations in malaria endemic countries [82]. Following reports of increasing $P$. vivax genetic diversity in Korea [84], Choi and colleagues used genotyping to successfully distinguish between autochthonous and imported $P$. vivax cases, identifying that the imported infections originated in neighbouring Asian countries. Imported infections also pose a risk in non-endemic regions of endemic countries. Many South American countries are geographically heterogeneous with regard to malaria transmission, and imported cases can result in serious illness and death amongst non-immune populations [85].

Genotyping imported infections is also essential to monitor the introduction and spread of drug resistance into sensitive populations. Population genetic surveys in Venezuela enabled identification of the introduction and spread of chloroquine resistant $P$. falciparum, resulting in changes to the national malaria treatment guidelines and rollout of more effective anti-malarials to combat the spread of drug resistance [82].

Combined, the results of these studies demonstrate the importance of population surveillance; to enable identification of routes of $P$. vivax introduction to, and transmission within, a given population. To achieve malaria elimination targets, the movement of $P$. vivax populations must be controlled to limit not only reintroduction of the disease into non-endemic countries, but also to restrict global genetic diversity and the spread of drug resistance.

\section{Impact assessment of intervention and vector control strategies}

Investigation of genetic diversity within $P$. vivax populations is a useful gauge of both the likelihood of success and subsequently, the impact of intervention methods. Interventions such as anti-malarials and candidate vaccines would be anticipated to be more successful in a population with low genetic diversity and any reduction in genetic diversity following the introduction of intervention measures may be regarded as an indicator of success.

In the absence of a continuous in vitro culture system and defined markers to identify drug resistance, genotyping is currently used to monitor treatment efficacy, and the emergence of resistant $P$. vivax strains. An understanding of haplotype frequency within a given population is therefore essential [86]. With respect to $P$. vivax parasites detected following drug treatment, there are three possible sources: re-infection with a new clone, recrudescence of a drug resistant clone, or relapse as a result of reactivation of liver hypnozoites [87]. As biomarkers do not currently exist to determine whether recurrent $P$. vivax parasitaemia is due to reactivation of liver hypnozoites, genotyping is used to identify whether recurrent episodes of $P$. vivax infection are the result of re-infection with a new clone or recrudescence/relapse of an existing drug-resistant clone $[87,88]$. The basis for this approach is that genetic diversity is sufficient to be able to distinguish between strains using a panel of diverse markers [86]. Confounding the distinction between relapse and re-infection, Imwong and colleagues reported that contrary to the long-held belief that reactivated hypnozoites were genetically identical to the strain responsible for primary infection, reactivated hypnozoites might indeed be heterologous [87]. Hence, it may not always be possible to distinguish re-infection from relapse, especially in regions with reduced parasite diversity. To maximize the ability to distinguish between strains, a panel of diverse markers should be used $[63,86,89]$. The markers used must be sufficiently diverse and located in distinct genomic positions, however markers may be more or less suited for use dependent upon genetic diversity within a given population $[27,63,86]$. As a result, community-based investigations of parasite diversity and allele frequencies are vital to enable accurate analysis of anti-malarial interventions $[27,86]$.

The impact of vector control strategies, such as insecticide spraying, is also measurable using population genetics methods. Jongwutiwes and colleagues reported differences in the diversity of $P$. vivax amongst populations in the north-west and south of Thailand [90]. Limited diversity, suggestive of a recent population bottleneck was observed in the south, where anti-malarial insecticide spraying had been implemented and was ongoing. In the north-west, a region bordering Myanmar, anti-malarial control measures have not been implemented to the same extent as in the south, and as a result, diversity of the $P$. vivax population investigated was high [90].

\section{Identification of immunogenic targets and potential vaccine candidates}

Development of a vaccine targeting $P$. vivax lags far behind efforts to design a vaccine against $P$. falciparum [91]. This is an inevitable reflection of the reduced research focus on $P$. vivax. The main obstacle impeding $P$. vivax research is the lack of available parasite material, since $P$. vivax cannot be continuously cultured in vitro and infected individuals typically present with low parasitaemia [92-95]. As a result, the majority of clinical immunology studies rely on using recombinant $P$. vivax proteins, typically expressed from reference strains [95]. However, an understanding of population genetic structure can also give insight into the development of host immune responses. Population genetics studies can identify signatures of balancing selection within parasite surface antigen genes, enabling identification of domains 
targeted by strong host immune pressure and thus identification of potential vaccine candidates, as has been done for $P$. falciparum $[23,96,97]$. The utility of diversity data is enhanced when additional information is known, such as the allelic frequency within a given population [96]. For example, in a population with low microsatellite diversity, low diversity amongst genes encoding antigens would also be expected. As strain-specific immunity is thought to be a major reason for the failure of malaria vaccine trials to date [98], reduced diversity amongst antigen-encoding genes would encode less diverse surface antigens, increasing the breadth of vaccine efficacy, and the generation of effective immune responses $[99,100]$.

There are three phases of the malaria parasite lifecycle that could be effectively targeted by host immune responses: inhibition of hepatocyte invasion at the preerythrocytic stage (e.g. vaccines targeting antigens such as CSP), inhibition of erythrocyte invasion during the asexual blood stage (merozoite surface protein 1, MSP1; apical membrane antigen 1, AMA1), and inhibition of parasite fertilization and development in the mosquito midgut (oocyst/ookinete $25 \mathrm{kD}$ surface protein, Pvs25) [91,101]. The majority of the vaccine candidates currently under investigation for $P$. vivax are orthologues of $P$. falciparum vaccine candidate antigens $[91,101]$. However, due to biological differences, and differences in the extent and distribution of genetic diversity, it is not always possible to draw conclusions for $P$. vivax on the basis of what is known for $P$. falciparum. Few studies have been performed to investigate the diversity of vaccine candidate antigens in sympatric populations. This is despite the fact that many believe a globally effective malaria vaccine must contain not only multiple antigens, but also a combination of $P$. falciparum and $P$. vivax antigens due to sympatric circulation of both species in many endemic regions [101]. Indeed, differences may exist between regions of the same antigen under immune pressure in $P$. falciparum and $P$. vivax parasites, as has been reported for AMA1 [97,102-104]. Assessment of genetic diversity, and therefore suitability of candidate antigens is therefore essential to design an effective multi-species and/or a $P$. vivax vaccine.

\section{Conclusions}

Partly as a consequence of the common misconception that $P$. vivax infection is benign, research funding and focus directed towards this neglected malaria parasite has been limited relative to $P$. falciparum. As a result, much remains unknown regarding $P$. vivax biology, epidemiology and pathogenesis. However, it is now understood that globally, $P$. vivax populations are highly genetically diverse, and that this diversity varies greatly according to geographic region. In order to achieve malaria control and elimination targets, population genetic surveys are vital to map the diversity and structure of local populations and to estimate the likelihood of success and measure the outcome of malaria intervention methods. To assist vaccine development, genetic structure and diversity of candidate antigens needs to be assessed in sympatric $P$. vivax and $P$. falciparum populations worldwide.

\section{Acknowledgements}

This work was supported by Project Grant 1003825 from the National Health and Medical Research Council (NHMRC) of Australia. JCR is supported by a NHMRC Principal Research Fellowship. This work was made possible through Victorian State Government Operational Infrastructure Support and Australian Government NHMRC IRIISS.

\section{Author details}

${ }^{1}$ Centre for Population Health, Burnet Institute, Melbourne, Australia. ${ }^{2}$ Division of Infection and Immunity, the Walter and Eliza Hall Institute for Medical Research, Parkville, Australia. ${ }^{3}$ Department of Medical Biology, University of Melbourne, Parkville, Australia. ${ }^{4}$ Department of Epidemiology and Preventative Medicine, Monash University, Melbourne, Australia.

\section{Authors' contributions}

AA drafted the paper. AEB and JCR provided input into scope and content and assisted in drafting the paper. All authors read and approved the final manuscript.

\section{Competing interests}

The authors declare that they have no competing interests.

Received: 13 October 2011 Accepted: 10 January 2012

Published: 10 January 2012

\section{References}

1. Guerra CA, Howes RE, Patil AP, Gething PW, Van Boeckel TP, Temperley WH, Kabaria CW, Tatem AJ, Manh BH, Elyazar IR, Baird JK, Snow RW, Hay SI: The international limits and population at risk of Plasmodium vivax transmission in 2009. PLoS Negl Trop Dis 2010, 4:e774.

2. Ferreira MU, Karunaweera ND, da Silva-Nunes M, da Silva NS, Wirth DF, Hartl DL: Population structure and transmission dynamics of Plasmodium vivax in rural Amazonia. J Infect Dis 2007, 195:1218-1226.

3. Kasehagen LJ, Mueller I, McNamara DT, Bockarie MJ, Kiniboro B, Rare L, Lorry K, Kastens W, Reeder JC, Kazura JW, Zimmerman PA: Changing patterns of Plasmodium blood-stage infections in the Wosera region of Papua New Guinea monitored by light microscopy and high throughput PCR diagnosis. Am J Trop Med Hyg 2006, 75:588-596.

4. Jun G, Yeom JS, Hong JY, Shin EH, Chang KS, Yu JR, Oh S, Chung H, Park JW: Resurgence of Plasmodium vivax malaria in the Republic of Korea during 2006-2007. Am J Trop Med Hyg 2009, 81:605-610.

5. Carme B, Ardillon V, Girod R, Grenier C, Joubert M, Djossou F, Ravachol F: Update on the epidemiology of malaria in French Guiana. Med Trop (Mars) 2009, 69:19-25.

6. Mendis K, Sina BJ, Marchesini P, Carter R: The neglected burden of Plasmodium vivax malaria. Am J Trop Med Hyg 2001, 64:97-106.

7. Price RN, Tjitra E, Guerra CA, Yeung S, White NJ, Anstey NM: Vivax malaria: neglected and not benign. Am J Trop Med Hyg 2007, 77:79-87.

8. Mueller I, Galinski MR, Baird JK, Carlton JM, Kochar DK, Alonso PL, del Portillo HA: Key gaps in the knowledge of Plasmodium vivax, a neglected human malaria parasite. Lancet Infect Dis 2009, 9:555-566.

9. Genton B, D'Acremont V, Rare L, Baea K, Reeder JC, Alpers MP, Muller I: Plasmodium vivax and mixed infections are associated with severe malaria in children: a prospective cohort study from Papua New Guinea. PLoS Med 2008, 5:e127.

10. Tjitra E, Anstey NM, Sugiarto P, Warikar N, Kenangalem E, Karyana M, Lampah DA, Price RN: Multidrug-resistant Plasmodium vivax associated 
with severe and fatal malaria: a prospective study in Papua, Indonesia. PLoS Med 2008, 5:e128.

11. Alexandre MA, Ferreira CO, Siqueira AM, Magalhaes BL, Mourao MP, Lacerda MV, Alecrim MG: Severe Plasmodium vivax malaria, Brazilian Amazon. Emerg Infect Dis 2010, 16:1611-1614.

12. Barcus MJ, Basri H, Picarima H, Manyakori C, Sekartuti, Elyazar I, Bangs MJ, Maguire JD, Baird JK: Demographic risk factors for severe and fatal vivax and falciparum malaria among hospital admissions in northeastern Indonesian Papua. Am J Trop Med Hyg 2007, 77:984-991.

13. Fernandez-Becerra C, Pinazo MJ, Gonzalez A, Alonso PL, del Portillo HA, Gascon J: Increased expression levels of the pvcrt-o and pvmdr1 genes in a patient with severe Plasmodium vivax malaria. Malar J 2009, 8:55.

14. Kochar DK, Das A, Kochar SK, Saxena V, Sirohi P, Garg S, Kochar A, Khatri MP, Gupta V: Severe Plasmodium vivax malaria: a report on serial cases from Bikaner in northwestern India. Am J Trop Med Hyg 2009, 80:194-198.

15. In Shrinking the Malaria Map: A Prospectus on Malaria Elimination. First edition. Edited by: Feachem RGA, Phillips AA, Targett GA. San Francisco: The Global Health Group, Global Health Sciences, University of California, San Francisco; 2009

16. The malERA Consultative Group on Drugs: A research agenda for malaria eradication: drugs. PLoS Med 2011, 8:e1000402.

17. Baird JK, Hoffman SL: Primaquine therapy for malaria. Clin Infect Dis 2004, 39:1336-1345.

18. Joshi H, Prajapati SK, Verma A, Kang'a S, Carlton JM: Plasmodium vivax in India. Trends Parasitol 2008, 24:228-235.

19. Schultz L, Wapling J, Mueller I, Ntsuke PO, Senn N, Nale J, Kiniboro B, Buckee CO, Tavul L, Siba PM, Reeder JC, Barry AE: Multilocus haplotypes reveal variable levels of diversity and population structure of Plasmodium falciparum in Papua New Guinea, a region of intense perennial transmission. Malar J 2010, 9:336.

20. Joy DA, Gonzalez-Ceron L, Carlton JM, Gueye A, Fay M, McCutchan TF, Su XZ: Local adaptation and vector-mediated population structure in Plasmodium vivax malaria. Mol Biol Evol 2008, 25:1245-1252.

21. Reid H, Vallely A, Taleo G, Tatem AJ, Kelly G, Riley I, Harris I, Henri I, lamaher S, Clements AC: Baseline spatial distribution of malaria prior to an elimination programme in Vanuatu. Malar J 2010, 9:150.

22. Grynberg P, Fontes CJ, Hughes AL, Braga EM: Polymorphism at the apical membrane antigen 1 locus reflects the world population history of Plasmodium vivax. BMC Evol Biol 2008, 8:123.

23. Cui L, Escalante AA, Imwong M, Snounou G: The genetic diversity of Plasmodium vivax populations. Trends Parasitol 2003, 19:220-226.

24. Baum J, Billker O, Bousema T, Dinglasan R, McGovern V, Mota MM, Mueller I, Sinden R: A research agenda for malaria eradication: basic science and enabling technologies. PLoS Med 2011, 8:e1000399.

25. Havryliuk T, Ferreira MU: A closer look at multiple-clone Plasmodium vivax infections: detection methods, prevalence and consequences. Mem Inst Oswaldo Cruz 2009, 104:67-73.

26. Karunaweera ND, Ferreira MU, Munasinghe A, Barnwell JW, Collins WE, King CL, Kawamoto F, Hartl DL, Wirth DF: Extensive microsatellite diversity in the human malaria parasite Plasmodium vivax. Gene 2008, 410:105-112.

27. Imwong M, Nair S, Pukrittayakamee S, Sudimack D, Williams JT, Mayxay M, Newton PN, Kim JR, Nandy A, Osorio L, Carlton JM, White NJ, Day NP, Anderson TJ: Contrasting genetic structure in Plasmodium vivax populations from Asia and South America. Int J Parasitol 2007, 37:1013-1022.

28. Van den Eede P, Van der Auwera G, Delgado C, Huyse T, Soto-Calle VE, Gamboa D, Grande T, Rodriguez H, Llanos A, Anne J, Erhart A, D'Alessandro U: Multilocus genotyping reveals high heterogeneity and strong local population structure of the Plasmodium vivax population in the Peruvian Amazon. Malar J 2010, 9:151.

29. Brito CF, Ferreira MU: Molecular markers and genetic diversity of Plasmodium vivax. Mem Inst Oswaldo Cruz 2011, 106:(Suppl 1):12-26.

30. Imwong M, Pukrittayakamee S, Gruner AC, Renia L, Letourneur F, Looareesuwan S, White NJ, Snounou G: Practical PCR genotyping protocols for Plasmodium vivax using Pvcs and Pvmsp1. Malar J 2005, 4:20.

31. Cui L, Mascorro CN, Fan Q, Rzomp KA, Khuntirat B, Zhou G, Chen H, Yan G, Sattabongkot J: Genetic diversity and multiple infections of Plasmodium vivax malaria in Western Thailand. Am J Trop Med Hyg 2003, 68:613-619.

32. Rungsihirunrat K, Chaijaroenkul W, Siripoon N, Seugorn A, Na-Bangchang K: Genotyping of polymorphic marker (MSP3alpha and MSP3beta) genes of Plasmodium vivax field isolates from malaria endemic of Thailand. Trop Med Int Health 2011, 16:794-801.

33. Van den Eede P, Erhart A, Van der Auwera G, Van Overmeir C, Thang ND, Hung le X, Anne J, D'Alessandro U: High complexity of Plasmodium vivax infections in symptomatic patients from a rural community in central Vietnam detected by microsatellite genotyping. Am J Trop Med Hyg 2010, 82:223-227.

34. Prajapati SK, Verma A, Adak T, Yadav RS, Kumar A, Eapen A, Das MK, Singh N, Sharma SK, Rizvi MA, Dash AP, Joshi H: Allelic dimorphism of Plasmodium vivax gam-1 in the Indian subcontinent. Malar J 2006, 5:90.

35. Kim JR, Imwong M, Nandy A, Chotivanich K, Nontprasert A, Tonomsing N, Maji A, Addy M, Day NP, White NJ, Pukrittayakamee S: Genetic diversity of Plasmodium vivax in Kolkata, India. Malar J 2006, 5:71.

36. Wickramarachchi T, Premaratne PH, Dias S, Handunnetti SM, UdagamaRandeniya PV: Genetic complexity of Plasmodium vivax infections in Sri Lanka, as reflected at the merozoite-surface-protein-3alpha locus. Ann Trop Med Parasitol 2010, 104:95-108.

37. Gunawardena S, Karunaweera ND, Ferreira MU, Phone-Kyaw M, Pollack RJ Alifrangis M, Rajakaruna RS, Konradsen F, Amerasinghe PH, Schousboe ML, Galappaththy GN, Abeyasinghe RR, Hartl DL, Wirth DF: Geographic structure of Plasmodium vivax: microsatellite analysis of parasite populations from Sri Lanka, Myanmar, and Ethiopia. Am J Trop Med Hyg 2010, 82:235-242.

38. Khatoon L, Baliraine FN, Bonizzoni M, Malik SA, Yan G: Genetic structure of Plasmodium vivax and Plasmodium falciparum in the Bannu district of Pakistan. Malar J 2010, 9:112.

39. Zakeri S, Raeisi A, Afsharpad M, Kakar Q, Ghasemi F, Atta H, Zamani G, Memon MS, Salehi M, Djadid ND: Molecular characterization of Plasmodium vivax clinical isolates in Pakistan and Iran using pvmsp-1, pvmsp-3alpha and pvcsp genes as molecular markers. Parasitol Int 2010 59:15-21.

40. Yang Z, Miao J, Huang Y, Li X, Putaporntip C, Jongwutiwes S, Gao Q, Udomsangpetch R, Sattabongkot J, Cui L: Genetic structures of geographically distinct Plasmodium vivax populations assessed by PCR/ RFLP analysis of the merozoite surface protein 3beta gene. Acta Trop 2006, 100:205-212

41. Zhong D, Bonizzoni M, Zhou G, Wang G, Chen B, Vardo-Zalik A, Cui L, Yan G, Zheng B: Genetic diversity of Plasmodium vivax malaria in China and Myanmar. Infect Genet Evol 2011, 11:1419-1425.

42. Kim TS, Kim HH, Lee SS, Na BK, Lin K, Cho SH, Kang YJ, Kim DK, Sohn Y, Kim H, Lee HW: Prevalence of Plasmodium vivax VK210 and VK247 subtype in Myanmar. Malar J 2010, 9:195

43. Moon SU, Lee HW, Kim JY, Na BK, Cho SH, Lin K, Sohn WM, Kim TS: High frequency of genetic diversity of Plasmodium vivax field isolates in Myanmar. Acta Trop 2009, 109:30-36.

44. Chen N, Auliff A, Rieckmann K, Gatton M, Cheng Q: Relapses of Plasmodium vivax infection result from clonal hypnozoites activated at predetermined intervals. J Infect Dis 2007, 195:934-941.

45. Zakeri S, Dinparast Djadid N, Zeinali S: Sequence heterogeneity of the merozoite surface protein-1 gene (MSP-1) of Plasmodium vivax wild isolates in southeastern Iran. Acta Trop 2003, 88:91-97.

46. Zakeri S, Abouie Mehrizi A, Djadid ND, Snounou G: Circumsporozoite protein gene diversity among temperate and tropical Plasmodium vivax isolates from Iran. Trop Med Int Health 2006, 11:729-737.

47. Zakeri S, Barjesteh H, Djadid ND: Merozoite surface protein-3alpha is a reliable marker for population genetic analysis of Plasmodium vivax. Malar J 2006, 5:53.

48. Severini C, Menegon M, Di Luca M, Abdullaev I, Majori G, Razakov SA, Gradoni L: Risk of Plasmodium vivax malaria reintroduction in Uzbekistan: genetic characterization of parasites and status of potential malaria vectors in the Surkhandarya region. Trans R Soc Trop Med Hyg 2004, 98:585-592.

49. Zakeri S, Safi N, Afsharpad M, Butt W, Ghasemi F, Mehrizi AA, Atta H, Zamani G, Djadid ND: Genetic structure of Plasmodium vivax isolates from two malaria endemic areas in Afghanistan. Acta Trop 2010, 113:12-19

50. Zeyrek FY, Tachibana S, Yuksel F, Doni N, Palacpac N, Arisue N, Horii T, Coban C, Tanabe K: Limited polymorphism of the Plasmodium vivax merozoite surface protein 1 gene in isolates from Turkey. Am J Trop Med Hyg 2010, 83:1230-1237. 
51. Sutton PL, Neyra V, Hernandez JN, Branch OH: Plasmodium falciparum and Plasmodium vivax infections in the Peruvian Amazon: propagation of complex, multiple allele-type infections without super-infection. Am J Trop Med Hyg 2009, 81:950-960.

52. Rezende AM, Tarazona-Santos E, Couto AD, Fontes CJ, De Souza JM, Carvalho LH, Brito CF: Analysis of genetic variability of Plasmodium vivax isolates from different Brazilian Amazon areas using tandem repeats. Am J Trop Med Hyg 2009, 80:729-733.

53. Rezende AM, Tarazona-Santos E, Fontes CJ, Souza JM, Couto AD, Carvalho LH, Brito CF: Microsatellite loci: determining the genetic variability of Plasmodium vivax. Trop Med Int Health 2010, 15:718-726.

54. Storti-Melo LM, de Souza-Neiras WC, Cassiano GC, Joazeiro AC, Fontes CJ, Bonini-Domingos CR, Couto AA, Povoa MM, de Mattos LC, Cavasini CE, Rossit AR, Machado RL: Plasmodium vivax circumsporozoite variants and Duffy blood group genotypes in the Brazilian Amazon region. Trans $R$ Soc Trop Med Hyg 2009, 103:672-678.

55. Orjuela-Sanchez P, da Silva NS, da Silva-Nunes M, Ferreira MU: Recurrent parasitemias and population dynamics of Plasmodium vivax polymorphisms in rural Amazonia. Am J Trop Med Hyg 2009, 81:961-968.

56. Veron V, Legrand E, Yrinesi J, Volney B, Simon S, Carme B: Genetic diversity of msp3alpha and msp1_b5 markers of Plasmodium vivax in French Guiana. Malar J 2009, 8:40

57. Bonilla JA, Validum L, Cummings R, Palmer CJ: Genetic diversity of Plasmodium vivax Pvcsp and Pvmsp1 in Guyana, South America. Am J Trop Med Hyg 2006, 75:830-835.

58. Cristiano FA, Perez MA, Nicholls RS, Guerra AP: Polymorphism in the Plasmodium vivax msp 3: gene in field samples from Tierralta, Colombia. Mem Inst Oswaldo Cruz 2008, 103:493-496.

59. Ord R, Polley S, Tami A, Sutherland CJ: High sequence diversity and evidence of balancing selection in the Pvmsp3alpha gene of Plasmodium vivax in the Venezuelan Amazon. Mol Biochem Parasitol 2005, 144:86-93.

60. Leclerc MC, Gauthier C, Villegas L, Urdaneta L: Genetic diversity of merozoite surface protein-1 gene of Plasmodium vivax isolates in mining villages of Venezuela (Bolivar State). Acta Trop 2005, 95:26-32.

61. Henry-Halldin CN, Sepe D, Susapu M, McNamara DT, Bockarie M, King CL, Zimmerman PA: High-throughput molecular diagnosis of circumsporozoite variants VK210 and VK247 detects complex Plasmodium vivax infections in malaria endemic populations in Papua New Guinea. Infect Genet Evol 2011, 11:391-398.

62. Mueller I, Kaiok J, Reeder JC, Cortes A: The population structure of Plasmodium falciparum and Plasmodium vivax during an epidemic of malaria in the Eastern Highlands of Papua New Guinea. Am J Trop Med Hyg 2002, 67:459-464.

63. Koepfli C, Mueller I, Marfurt J, Goroti M, Sie A, Oa O, Genton B, Beck HP Felger I: Evaluation of Plasmodium vivax genotyping markers for molecular monitoring in clinical trials. J Infect Dis 2009, 199:1074-1080.

64. Gomez JC, MCNamara DT, Bockarie MJ, Baird JK, Carlton JM, Zimmerman PA: Identification of a polymorphic Plasmodium vivax microsatellite marker. Am J Trop Med Hyg 2003, 69:377-379.

65. Anderson TJ, Haubold B, Williams JT, Estrada-Franco JG, Richardson L, Mollinedo R, Bockarie M, Mokili J, Mharakurwa S, French N, Whitworth J, Velez ID, Brockman AH, Nosten F, Ferreira MU, Day KP: Microsatellite markers reveal a spectrum of population structures in the malaria parasite Plasmodium falciparum. Mol Biol Evol 2000, 17:1467-1482.

66. Mu J, Awadalla P, Duan J, McGee KM, Joy DA, McVean GA, Su XZ: Recombination hotspots and population structure in Plasmodium falciparum. PLOS Biol 2005, 3:e335

67. Anderson TJ, Su XZ, Bockarie M, Lagog M, Day KP: Twelve microsatellite markers for characterization of Plasmodium falciparum from finger-prick blood samples. Parasitology 1999, 119(Pt 2):113-125.

68. Imwong M, Sudimack D, Pukrittayakamee S, Osorio L, Carlton JM, Day NP, White NJ, Anderson TJ: Microsatellite variation, repeat array length, and population history of Plasmodium vivax. Mol Biol Evol 2006, 23:1016-1018.

69. Russell B, Suwanarusk R, Lek-Uthai U: Plasmodium vivax genetic diversity: microsatellite length matters. Trends Parasitol 2006, 22:399-401.

70. Leclerc MC, Durand P, Gauthier C, Patot S, Billotte N, Menegon M, Severini C, Ayala FJ, Renaud F: Meager genetic variability of the human malaria agent Plasmodium vivax. Proc Natl Acad Sci USA 2004, 101:14455-14460.
71. de Souza-Neiras WC, de Melo LM, Machado RL: The genetic diversity of Plasmodium vivax-a review. Mem Inst Oswaldo Cruz 2007, 102:245-254.

72. Koepfli C, Schoepflin S, Bretscher M, Lin E, Kiniboro B, Zimmerman PA, Siba $P$, Smith TA, Mueller I, Felger I: How much remains undetected? Probability of molecular detection of human plasmodia in the field. PLOS One 2011, 6:e19010.

73. Bruce MC, Galinski MR, Barnwell JW, Donnelly CA, Walmsley M, Alpers MP, Walliker D, Day KP: Genetic diversity and dynamics of plasmodium falciparum and $P$. vivax populations in multiply infected children with asymptomatic malaria infections in Papua New Guinea. Parasitology 2000, 121(Pt 3):257-272

74. Daubersies P, Sallenave-Sales S, Magne S, Trape JF, Contamin H, Fandeur T, Rogier C, Mercereau-Puijalon O, Druilhe P: Rapid turnover of Plasmodium falciparum populations in asymptomatic individuals living in a high transmission area. Am J Trop Med Hyg 1996, 54:18-26.

75. Guerra CA, Hay SI, Lucioparedes LS, Gikandi PW, Tatem AJ, Noor AM, Snow RW: Assembling a global database of malaria parasite prevalence for the Malaria Atlas Project. Malar J 2007, 6:17.

76. Moonen B, Cohen JM, Snow RW, Slutsker L, Drakeley C, Smith DL, Abeyasinghe RR, Rodriguez MH, Maharaj R, Tanner M, Targett G: Operational strategies to achieve and maintain malaria elimination. Lancet 2010, 376:1592-1603.

77. The Pacific Malaria Initiative Survey Group (PMISG) on behalf of the Ministries of Health of Vanuatu and Solomon Islands: Malaria on isolated Melanesian islands prior to the initiation of malaria elimination activities. Malar J 2010, 9:218.

78. Maguire JD, Bangs MJ, Brennan L, Rieckmann K, Taleo G: Cross-sectional characterization of malaria in Sanma and Shefa Provinces, Republic of Vanuatu: malaria control implications. P N G Med J 2006, 49:22-31.

79. Maitland K, Williams TN, Peto TE, Day KP, Clegg JB, Weatherall DJ, Bowden DK: Absence of malaria-specific mortality in children in an area of hyperendemic malaria. Trans R Soc Trop Med Hyg 1997, 91:562-566.

80. Hii JL, Kanai L, Foligela A, Kan SK, Burkot TR, Wirtz RA: Impact of permethrin-impregnated mosquito nets compared with DDT housespraying against malaria transmission by Anopheles farauti and An. punctulatus in the Solomon Islands. Med Vet Entomol 1993, 7:333-338.

81. Feachem R, Sabot O: A new global malaria eradication strategy. Lancet 2008, 371:1633-1635.

82. Rodriguez-Morales AJ, Delgado L, Martinez N, Franco-Paredes C: Impact of imported malaria on the burden of disease in northeastern Venezuela. J Travel Med 2006, 13:15-20.

83. Khan FY, Lutof AK, Yassin MA, Khattab MA, Saleh M, Rezeq HY, Almaslamani M: Imported malaria in Qatar: a 1 year hospital-based study in 2005. Travel Med Infect Dis 2009, 7:111-117.

84. Choi KM, Choi YK, Kang YA, Seo SY, Lee HW, Cho SH, Lee WJ, Rhie HG, Lee HS, Kim JY: Study of the genetic discrimination between imported and autochthonous cases of malaria in South Korea. J Travel Med 2011, 18:63-66.

85. Rodriguez-Morales AJ, Ferrer MV, Barrera MA, Pacheco M, Daza V, FrancoParedes C: Imported cases of malaria admitted to two hospitals of Margarita Island, Venezuela, 1998-2005. Travel Med Infect Dis 2009, 7:44-48.

86. Gatton ML, Cheng Q: Can estimates of antimalarial efficacy from field studies be improved? Trends Parasitol 2008, 24:68-73.

87. Imwong M, Snounou G, Pukrittayakamee S, Tanomsing N, Kim JR, Nandy A, Guthmann JP, Nosten F, Carlton J, Looareesuwan S, Nair S, Sudimack D, Day NP, Anderson TJ, White NJ: Relapses of Plasmodium vivax infection usually result from activation of heterologous hypnozoites. J Infect Dis 2007, 195:927-933.

88. Teka H, Petros B, Yamuah L, Tesfaye G, Elhassan I, Muchohi S, Kokwaro G, Aseffa $\mathrm{A}$, Engers $\mathrm{H}$ : Chloroquine-resistant Plasmodium vivax malaria in Debre Zeit, Ethiopia. Malar J 2008, 7:220.

89. Havryliuk T, Orjuela-Sanchez P, Ferreira MU: Plasmodium vivax: microsatellite analysis of multiple-clone infections. Exp Parasitol 2008, 120:330-336.

90. Jongwutiwes S, Putaporntip C, Hughes AL: Bottleneck effects on vaccinecandidate antigen diversity of malaria parasites in Thailand. Vaccine 2010, 28:3112-3117

91. Galinski MR, Barnwell JW: Plasmodium vivax: who cares? Malar J 2008, 7(Suppl 1):S9. 
92. Golenda CF, Li J, Rosenberg R: Continuous in vitro propagation of the malaria parasite Plasmodium vivax. Proc Natl Acad Sci USA 1997, 94:6786-6791

93. Mons B, Collins WE, Skinner JC, van der Star W, Croon JJ, van der Kaay HJ: Plasmodium vivax: in vitro growth and reinvasion in red blood cells of Aotus nancymai. Exp Parasitol 1988, 66:183-188.

94. Chotivanich K, Silamut K, Udomsangpetch R, Stepniewska KA, Pukrittayakamee S, Looareesuwan S, White NJ: Ex-vivo short-term culture and developmental assessment of Plasmodium vivax. Trans $R$ Soc Trop Med Hyg 2001, 95:677-680.

95. Gentil F, Bargieri DY, Leite JA, Francoso KS, Patricio MB, Espindola NM, Vaz AJ, Palatnik-de-Sousa CB, Rodrigues MM, Costa FT, Soares IS: A recombinant vaccine based on domain II of Plasmodium vivax Apical Membrane Antigen 1 induces high antibody titres in mice. Vaccine 2010, 28:6183-6190.

96. Weedall GD, Conway DJ: Detecting signatures of balancing selection to identify targets of anti-parasite immunity. Trends Parasitol 2010, 26:363-369.

97. Gunasekera AM, Wickramarachchi T, Neafsey DE, Ganguli I, Perera L, Premaratne PH, Hartl D, Handunnetti SM, Udagama-Randeniya PV, Wirth DF: Genetic diversity and selection at the Plasmodium vivax apical membrane antigen-1 (PvAMA-1) locus in a Sri Lankan population. Mol Biol Evol 2007, 24:939-947.

98. Richards JS, Beeson JG: The future for blood-stage vaccines against malaria. Immunol Cell Biol 2009, 87:377-390.

99. Dias S, Longacre S, Escalante AA, Udagama-Randeniya PV: Genetic diversity and recombination at the $\mathrm{C}$-terminal fragment of the merozoite surface protein-1 of Plasmodium vivax (PvMSP-1) in Sri Lanka. Infect Genet Evol 2011, 11:145-156.

100. Ferreira MU, da Silva Nunes M, Wunderlich G: Antigenic diversity and immune evasion by malaria parasites. Clin Diagn Lab Immunol 2004, 11:987-995.

101. Arevalo-Herrera M, Chitnis C, Herrera S: Current status of Plasmodium vivax vaccine. Hum Vaccin 2010, 6:124-132.

102. Remarque EJ, Faber BW, Kocken CH, Thomas AW: Apical membrane antigen 1: a malaria vaccine candidate in review. Trends Parasitol 2008, 24:74-84.

103. Ord RL, Tami A, Sutherland CJ: ama1 genes of sympatric Plasmodium vivax and $P$. falciparum from Venezuela differ significantly in genetic diversity and recombination frequency. PLoS One 2008, 3:e3366.

104. Polley SD, Chokejindachai W, Conway DJ: Allele frequency-based analyses robustly map sequence sites under balancing selection in a malaria vaccine candidate antigen. Genetics 2003, 165:555-561.

\section{doi:10.1186/1475-2875-11-14}

Cite this article as: Arnott et al:: Understanding the population genetics of Plasmodium vivax is essential for malaria control and elimination. Malaria Journal 2012 11:14.

\section{Submit your next manuscript to BioMed Central and take full advantage of:}

- Convenient online submission

- Thorough peer review

- No space constraints or color figure charges

- Immediate publication on acceptance

- Inclusion in PubMed, CAS, Scopus and Google Scholar

- Research which is freely available for redistribution 